\title{
CONSIDERATIONS REGARDING THE PLANNING OF PROTECTED AREAS ARISING FROM A STUDY OF THE TUSCANIA NATURAL RESERVE (CENTRAL ITALY)
}

\author{
Antonio Leone, Luca Ceccarelli, M. Nicolina Ripa, Fabio Recanatesi
}

\section{Introduction}

The International Union for the Conservation of Nature (IUCN) defines a Protected Area (PA) as: An area of land and/or sea especially dedicated to the protection and maintenance of biological diversity, and of natural resources and associated cultural resources, and managed through legal or other effective means [IUCN 1994].

PAs are increasing worldwide, and now cover over $12 \%$ of the entire earth surface [Council of EuropeUNEP 2004]. This evolution, inevitably, means that more attention should be given to PA management and, in particular, to the sustainability of human activities within and around PAs. Consequently, land use planning becomes a necessary process that should provide [IUCN 1994]:

- Protected Areas Plans (PAPs), long-term frameworks for directing and stimulating sustainable development, provision of infrastructures etc., operating in the public interest, without prejudice coming from private interests;

- planning should be open to public scrutiny and comment;

- any national legislative system should apply more stringent procedures and/or policies within protected areas, to accommodate their special needs.

Italian legislative organization reflects these aims: it is based on law No. 394 of 1991, which defines a protected area (of national or regional interest) as an area that represents the natural heritage, the physical (geological, geo-morphological, hydrological etc.) and biological formations, or groups of them, with important naturalistic and environmental value.

Paper received 02.08.2010; accepted 26.06.2011

A. Leone, Full Professor; L. Ceccarelli, PhD; M.N. RiPA, Associate Professor; F. RECANATESI, Researcher. Tuscia University - DAFNE Department, Land Management Engineering Group, Via S. Camillo de Lellis, Viterbo (Vt) - ITALY zip code 01100.

Corresponding author: Prof. Antonio Leone, leone@unitus.it.Telephone number: +390761357363 Fax number: +390761357250

The contribution to this article of each author has to be considered equally shared.
In Western Europe generally, and in particular in Italy, the landscape has changed a great deal since the 1950 s and '60s, with the shift from an economy based on agriculture, to an industrial economy, as a result of the profound social and economic revolution which occurred in the post-war period [Palang 2005].

This has led to new and greater threats to the environment and biodiversity, necessitating the institution and development of protected areas. As a result, in European landscapes a process of polarization has taken place between intensive land use and naturalistic areas [Jongman 2002]. This is not a positive process, because polarization is in contrast with the principles of sustainable development, which instead are necessarily holistic. Furthermore, in Europe, and especially in Italy, all landscapes can be considered cultural, being the result of a long process of land reorganization aimed at adapting its use and structure to the demands of society [Antrop 2005].

Therefore, apart from the "traditional" role of parks in biodiversity conservation, they should also play a role in cultural landscape protection, increasing the link between culture (human settlements, traditional agriculture, heritage etc.) and nature, as set out in the European Landscape Convention of Florence [2000]. This is particularly true for Italian and many European rural landscapes, where "traditional" land management has been abandoned, in favour of intensive agriculture or urban sprawl [Marignani 2008; Pelorosso 2009].

Landscape management and environmental sustainability are general needs of society and one way in which protected areas can contribute to the pursuit of sustainability is by testing methods which can then be applied to the whole territory.

In this direction, a fundamental tool is the PAP, whose main processes are:

1) Zoning the PA area and its consequent land organisation. Italian law provides four main zones (and, possibly, sub-zones), with a core area where human presence is strongly limited or forbidden, and three other zones, in which the limitations to human activity gradually decrease. Zoning is adopted in the PAPs of most countries [Beresford 2000; Phillips 
2002; Benkhard 2004], even though many zoning designs are still unsatisfactory, because they are too subjective [Liu 2008], or not well integrated with other planning processes.

2) Defining the park buffer zone. A further, special zone is the area surrounding the protected area, outside the park, but which interacts with it, characterised by special land management, planned within the PAP itself and aimed at ensuring the functionality of the protected area.

3) Involving local people and stakeholders in the planning process. A high level of public participation, understanding and acceptance (and, if necessary, compensation) is a fundamental planning factor [Forrester 1989].

4) Integrating the PAP with other environmental and land planning processes. It is important not only to stress sustainability, while taking into account development [Friedman 1992], but also to consider parks as areas where experience can be accumulated regarding innovative conservation methods for all resources, not only biodiversity: air, soil and water conservation [Buisson 2006].

The application of these processes to PAPs is aimed at developing the latter, shifting from "static" fencing for "special" landscapes, towards a "dynamic" use of resources throughout the whole territory [Giacomini 1982]. There has been little scientific debate on this subject although a few integrated analyses of the above mentioned four processes are available in the literature [Baudry 2004]. In fact, scientific literature on PAs generally focuses either on the effect of single processes on wildlife, or, on the contrary, on the local people's and tourists' perception of a PA [Shafer 1999]. For example, [Young 1997] and [Mitchel 2002] considered the general problem of wildlife conservation in cultural landscapes; [Trakolis 2001; Lacitignola 2007; Suckall 2009] debated local people's perceptions of rural landscapes and related planning and management, in Greek, Italian and British PAs, respectively; [Liu 2008] discussed zoning aimed at maintaining ecological functions and sustainable development for giant panda protection; [Marignani 2008] proposed a standardized method for developing restoration practices aimed at increasing the efficacy of landscape management. Another much debated topic is PA design, aimed at ensuring optimal biological connectivity [Kingsland 2002; Williams 2005; Opdam 2006].

An integrated analysis is important not only for PA management, but also (and above all) for the general aim of environmental protection and sustainability, constituting a bridge between scientific and socioeconomic issues. Thus, while the role of PAs in protecting biological diversity is clear, more experience is needed regarding general sustainable development, above all for the specific category of nature reserves classified by the IUCN as a "Protected Landscape" [Category V of the IUCN classification, 1994], i.e.: an area of land where the interaction of people and nature over time has produced a distinct character, with significant aesthetic, ecological and cultural value [IUCN 1994]. The Italian Framework Law No. 394 of 1991 does not distinguish between IUCN categories, and, therefore, it does not provide for this specific category. It is a significant limitation, because, practically speaking, all Italian (and, indeed, all European) landscapes are cultural, i.e. the product of human activities, heritage and nature. This is the landscape definition of the European Landscape Convention (ELC), which means that PAs should, in fact, deal with socio-economic issues. In consequence, PAPs and landscape plans deriving from the ELC should be much more integrated, hence the need for further experience and debate on integration. In fact, the scientific debate regarding landscape assessment for sustainable planning which takes into consideration cultural landscape multi-functionality, is recent [Willemen 2010] and a special effort is required in PA planning evolution.

This paper discusses a study regarding planning processes, related to the role of development sustainability in protected areas which could be considered as belonging to the V IUCN Category of "Protected Landscapes". This is generally a significant issue for these territories, where human presence is relevant and a fear that the establishment of a new territory administration (PA management) may cause harm to the local economy is very frequent.

In summary, starting from an Italian case study, this paper aims to perform a critical analysis of PA planning processes, to formulate proposals of general interest to improve the latter, and to increase the role of PAs in general land management. The specific aims of this paper, within this context, consist in searching for ways to integrate PAPs with other territorial plans, not only environmental conservation, and to improve the efficiency of the former.

\section{Materials and methods}

The case study refers to the plan for the Tuscania Nature Reserve (Fig. 1: Lazio Region, central Italy, about $90 \mathrm{~km}$ north of Rome), under the provisions of the National and Regional laws, respectively: $n$. 394/1991 and n. 29/1997.

For thousands of years, the Tuscania area has been affected by the presence of man. It was already an important centre in the Etruscan period (from XI until III century B.C.). Later, it passed under Roman dominion until the V century A.D., and was part of the Church State territories, until the Italian State was founded in 1861.

The Tuscania Natural Reserve (TNR) is a highly valuable landscape, generated by thousands of years of integration of nature with culture (agricultural, forestry and pasture activities), typical of the central Italian Apennines and significant from a European point of view, being typical of the majority of 


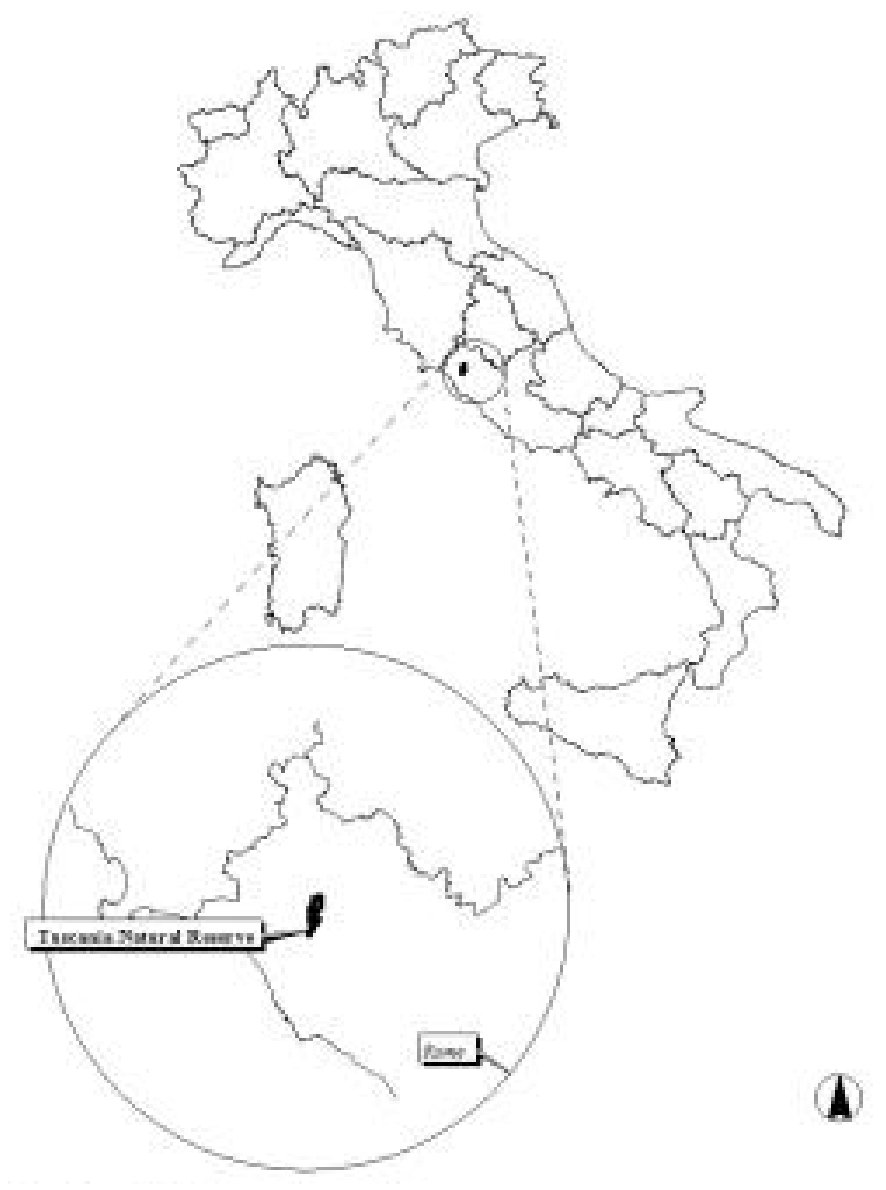

Fig. 1 - The investigated area.

Mediterranean landscapes [Clement 2008]. It owes its origins to traditional hill farming practices, which generated a semi-natural habitat, formed by extensive agricultural, pasture and forestry activities.

The TNR covers an area of 1901 ha, which includes: the town of Tuscania, founded in the high medieval period; some of the richest archaeological sites of the Etruscan and Roman ages in the Lazio region; some very important medieval buildings and Romanic basilicas (XI Century). In the valleys overlooking the streams, in the rock face (volcanic tuff), there are Etruscan cellar tombs, mostly dug inside the rock, that archaeologists judge to have contained many hundreds (perhaps thousands) of individuals. In fact, they are so large that during the medieval period, entire families inhabited them [Scardozzi 2003].

The landscape morphology consists of gently rolling hills; the Marta River runs through the entire protected area, creating, together with its tributaries, very narrow valleys, rich in vegetation and very important biotopes, related to freshwater. In fact, the Marta River is a habitat of European interest, as defined by the EC "Habitat" Directive [No. 92/43/EC], thanks to the presence of many fish species: Leuciscus souffia [92/43/EC code 1131], Lampetra planeri [code 1096], Alosa fallax (code 1103), Rutilus rubilio [code 1136], Barbus plebejus [code 1137], Padogobius ni- gricans [code 1156], Salaria fluviatilis [code 1152].

These species are seriously threatened by the following factors, which have dramatically reduced them as assessed by one year surveys related to planning activities [Boccia 2007]:

a) The outlet of Lake Bolsena, the level of which is regulated mainly as a result of drawing water for irrigation, thus often dramatically reducing the river water flow in drought periods.

b) Four hydroelectric power plants, which involve canalization of the water course and barrage by dams.

c) The wastewaters from domestic sewage (about 10000 inhabitant equivalent) and industrial sewage (mainly produced by a paper-mill and a slaughterhouse for sheep). They are all characterized by insufficient disinfection/treatment [Boccia 2007].

Inevitably, the PAP cannot avoid tackling these problems, which are at the origin of the threat to biodiversity, because a plan that limits its action to flora and fauna will never really be able to solve problems at their source.

This statement has been the planning process benchmark.

The main planning processes, that became the guide for the different planning phases and processes, are as follows:

a) Zoning: functional subdivision into four main zones (A, B, C, D), in particular: zone A: Integral reserve, where the habitat is preserved in its integrity; zone B: general reserve, where a "light" human presence can be admissible; zone $C$ : Protection zone, where productive activities can be allowed; zone D: Economic and social development areas.

b) The definition of the protected area's boundary, based on the study and on a hearing involving landowners, and on a broader process of public involvement in the planning process.

c) The definition and regulation of the surrounding $P A$ territories (PA buffer area).

d) The preparation of the Management Regulation document. This document is required by law 394/1991 and is the fundamental act for PA territory management, which states the management rules, outlining future PA stewardship actions.

Particular care was dedicated to the involvement of the park community, also considering that, in the setting up phase of the PA, many people declared their opposition to it. This work was pursued by a series of meetings, workshops, interviews, analyses of land policy documents and also simple talks and "quasi" confidential talks with all those subjects, both public and private, who wanted to communicate needs regarding the TNR. A "Park Office" was opened during the planning phase (for about 18 months), with the constant presence of students and young researchers, to give an immediate support to the community, to collect suggestions and evaluate the population's attitude to the park. 
This work was also aimed at understanding (and overcoming) the reasons behind people's opposition to the creation of the TNR.

In particular, meetings were held with the main local power organisations:

1. Farmers' associations. Farmers and hunters are essentially the same group of people. Particular care was dedicated to explaining the planning strategies for the agricultural land and for the control of wild fauna. This allowed the planners the opportunity to understand the source of hostilities: in a few cases, it was due to illegal activities and the consequent fear of increasing land control, but most hostility was generated by a general, irrational fear of change. The social structure of these groups is quite simple: they are small landowners, very jealous of their properties, partly because they were acquired recently, with the 1950s Italian agrarian reform and partly because, historically, Italian rural society depended on elite powers, with a hierarchical and paternalistic social stratification, closed and diffident towards any change. The new owners inherited this frame of mind and, hence, they are diffident towards any central power, which they considered distant and hostile.

The information thus gathered allowed the planners to devise and implement a strategy to overcome the population's diffidence.

2. Paper mill owners. Special attention was paid to this industry, which is on the Marta River, inside the protected area. It is not only the most important industry in the area, but also the main cause of pollution in the river. Again, the planning action and the meetings with the owners were based on a collaborative attitude, leaving them the initiative for proposals in PA management. This attitude did not exist before, when the only contact of owners with territory authorities was in the form of inspections of environmental policy. The planning action started from the assumption of the social role of the factory, which employs about 40 workers in a town of about 7000 inhabitants. Therefore, any immediate, strong coercive action was judged to be wrong, while the main planning objectives was an evaluation of how the present productive cycle could be improved to reduce pollution loads in the Marta river and to adopt the IPPC procedure (European Directive, No. 96/61/CE, and its application in Italy). Only in a successive phase, the plan provides for relocating the factory, leaving this measure to the TNR management, which will pursue this action only after having reached an agreement on it with the owners, workers and local administration. This will require a long time, not compatible with the planning phase.

3. Hydroelectric power station Company. Four small hydroelectric power plants lie on the Marta River, in the TNR territory. Obviously, they interrupt the river's continuity, affecting its hydrology and habitat, and in particular representing a barrier for fish.
This problem was also faced by cooperation with the plant managers, who agreed in principle, subscribing a written document, to the proposal of substituting the plants with other renewable source energy plants in the zone.

This proposal will require a long time to implement, so the plan leaves this problem to the TNR management, while providing a frame within which to act, i.e.:

a. the hydro-electrical plants will be substituted by energy production using other renewable sources (the company is above all interested in wind energy);

b. the current plant structures will be used for a water museum and other tourist opportunities;

c. the habitat of the currently canalised Marta river courses will be restored.

4. Ecologist associations. Meetings were arranged with all the associations active in the region, submitting a written document containing an outline of the plan, the contents of which were agreed to by the associations.

5. Regional Park Agency of the Lazio Region Administration. The plan was explained in its essential lines, obtaining an agreement in principle from this agency.

\section{Results}

The territory characterization carried out with the work illustrated in the "Materials and methods" Section, highlights the fundamental characteristics of the TNR's resources:

a) the natural components, in particular, the Marta river, with its habitat for freshwater wildlife and its canyons and its vulnerability to pollution;

b) the landscape, with its cultural and historical features and its integration of "agricultural-forestrypasture" systems, which have remained substantially unchanged up to the present;

c) the historical heritage: the medieval old town and the older Etruscan remains, the widespread presence of archaeological sites (pottery fragments) and, above all, the beautiful Etruscan tombs and medieval buildings scattered throughout the territory.

On the basis of this synthesis of the studies carried on, two main vocations of the PA emerge: TNR can be defined as an "archaeological park", considering its ancient history, and as a "rural park", considering the period since the Middle Ages to the present.

Regarding sustainability, the real environmental threats are posed by the quantity and quality of the water in the River Marta. Water quantity depends on the heavy spills from Lake Bolsena. This process suggested the design of the TNR buffer territory to the planners (see § 3.2). Water quality, instead, depends on the above-mentioned problem of the presence of factories and sewers which pollute the river. This suggests more urgent projects. 


\begin{tabular}{|c|c|c|c|c|}
\hline \multicolumn{5}{|c|}{ Zone A, Integral reserve } \\
\hline $\begin{array}{l}\text { Sub- } \\
\text { zone }\end{array}$ & Tutelage characteristics & Landscape characteristics & $\begin{array}{l}\text { Percentage } \\
\text { area }(\%)\end{array}$ & Prescriptions \\
\hline \multicolumn{5}{|c|}{ Zone A, Integral reserve } \\
\hline B2 & Partial tutelage. & $\begin{array}{l}\text { Buffer } 150 \mathrm{~m} \text { on either side of } \\
\text { the river. }\end{array}$ & 25.55 & 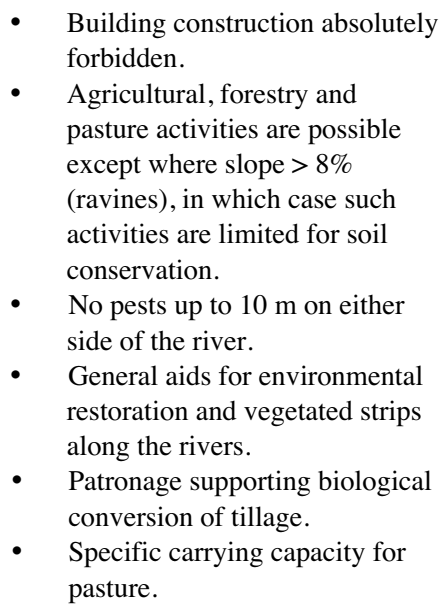 \\
\hline B3 & Partial tutelage. & Woods. & 20.95 & $\begin{array}{l}\text { The PAP gives guidelines for } \\
\text { management. } \\
\text { Forestry exploitation is possible, } \\
\text { with restrictions on steeper slopes } \\
\text { (ravines). }\end{array}$ \\
\hline $\mathrm{C} 1$ & Sustainable exploitation. & Normal agricultural areas. & 41.81 & $\begin{array}{l}\text { - } \\
\text { Agriculture is possible. } \\
\text { Patronage for PA managers to } \\
\text { perform a code for best } \\
\text { practices, in synergy with } \\
\text { farmers. } \\
\text { - Specific carrying capacity for } \\
\text { pasture. }\end{array}$ \\
\hline $\mathrm{C} 2$ & Sustainable exploitation. & $\begin{array}{l}\text { Agricultural areas contiguous to } \\
\text { the town. }\end{array}$ & 4.70 & $\begin{array}{l}\text { - } \quad \text { Agriculture is possible. } \\
\text { - Pest limitations. }\end{array}$ \\
\hline $\mathrm{C} 3$ & Sustainable exploitation. & $\begin{array}{l}\text { Agricultural areas close to } \\
\text { Etruscan groves ( } 20 \mathrm{~m} \text { buffer). } \\
\text { Agricultural areas in the } \\
\text { Etruscan reverts (fictile } \\
\text { fragments) zone. }\end{array}$ & 0.04 & $\begin{array}{l}\text { Agriculture is possible, but } \\
\text { tillage must not be deeper than } \\
30 \mathrm{~cm} \text {. } \\
\text { For deeper digging (to plant } \\
\text { trees or building construction), } \\
\text { the PA management and the } \\
\text { State Heritage Superintendence } \\
\text { must be advised. }\end{array}$ \\
\hline \multicolumn{5}{|c|}{ Zone D, Development areas } \\
\hline D1 & $\begin{array}{l}\text { Socio-economic development } \\
\text { area. }\end{array}$ & Paper mill. & 0.19 & $\begin{array}{l}\text { - Patronage for IPPC } \\
\text { certification. } \\
\text { Specific guidelines from the } \\
\text { PAP. }\end{array}$ \\
\hline
\end{tabular}

TABLE 1 - Details on Tuscania Natural Reserve zoning. 
D4

D5

Socio-economic development Town medieval centre. area.
Socio-economic development area.

Socio-economic development area.
New constructions area from the $\quad 0.30$ town Master plan. treatment.

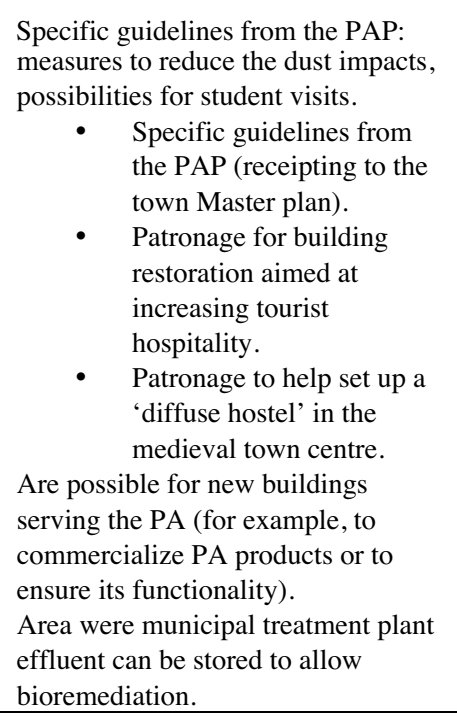

Specific guidelines from the PAP: measures to reduce the dust impacts, the PAP (receipting to the town Master plan) restoration aimed at increasing tourist ospitality. 'diffuse hostel' in the medieval town centre

ble for new buildings serving the PA (for example, to ensure its functionality).

effluent can be stored to allow bioremediation.

These considerations provide the milestones of the TNR, detailed in the following paragraph and in Table 1.

\subsection{Zoning}

The planned TNR zoning is reported in Fig. 2. The main criteria to support these choices are:
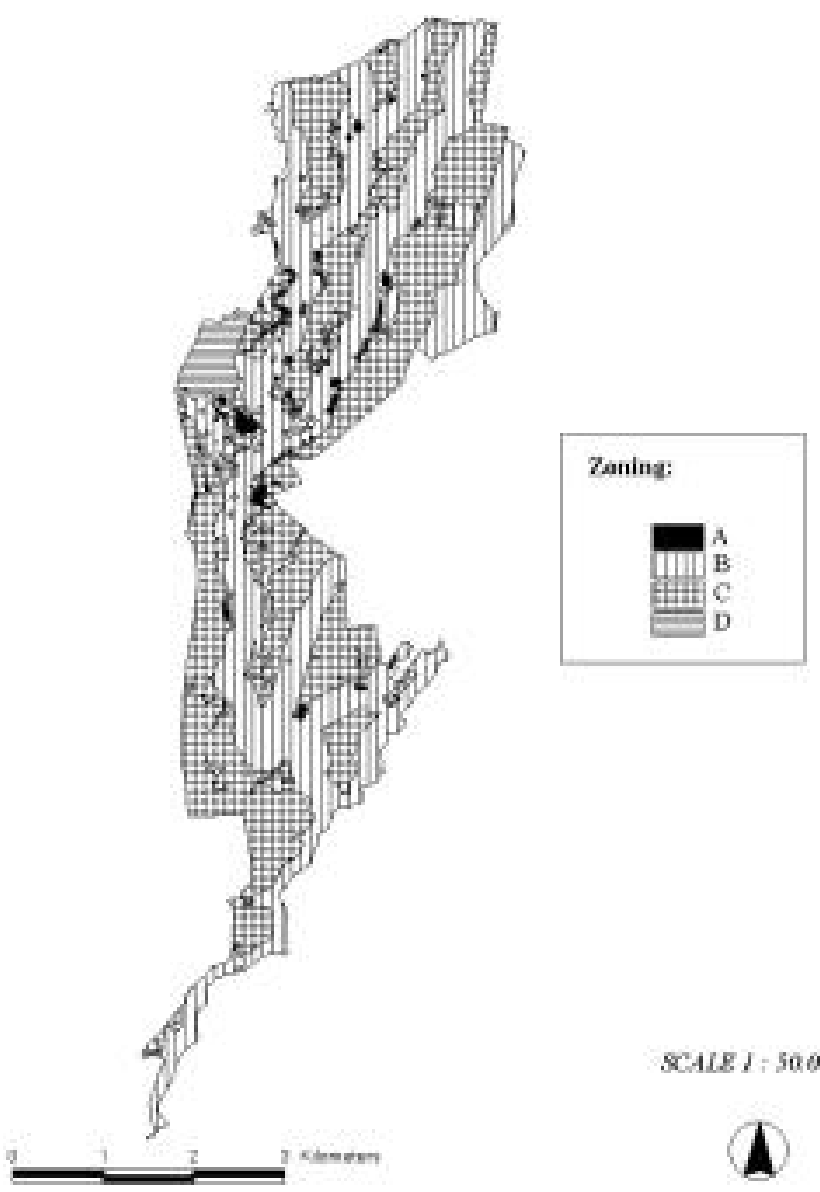

Fig. 2 - Main zoning items for the Tuscania Natural Reserve.
- A zones. Considering the character of the TNR, an absolute conservation regime is absent. The A zone comprises just the Etruscan tombs, where only scientific activity is permitted.

- $B$ zones. The most important natural areas in these zones are the woods and, above all, the Marta river, with its species of European Community Interest [92/43/EC Directive].

- $C$ zones. Here the goal of the plan is to eliminate or mitigate the impact of human activity, maintaining and increasing opportunities leading to sustainable development. "Agricultural-forestry-pasture" activities are allowed and the farmhouse tourist business is encouraged (C1 sub-zone). Except for special cases of cultivation in areas characterised by steep slopes, the present agricultural systems are considered sustainable, with the exception of areas scattered with archaeological pottery fragments, which have to be safeguarded from any deep ploughing. For these areas, an opportune sub-zone (C2) was provided, limiting ploughing more than $30 \mathrm{~cm}$ below the surface.

- $D$ Zones. They are generally areas already modified by human settlements and the medieval town. The focus is on the most sensitive structures: the hydroelectric power plants, the paper mill and the Tuscania sewage treatment plant.

\subsection{The buffer area}

The proposal put forward in the TNR plan for the contiguous area (CA) is not a generic buffer around its boundary, as is the common practice. It is based, instead, on the legal definition of CAs [Italian law No. 394/1991]: "areas not belonging to the protected territory, but that could contribute to its environmental protection".

Thus defined, the TNR contiguous area comprises the River Marta basin, measured from the down valley river section in the TNR territory and contains the whole upper Marta watershed, as far as Lake Bolsena, including eight municipalities [Fig. 3]. 


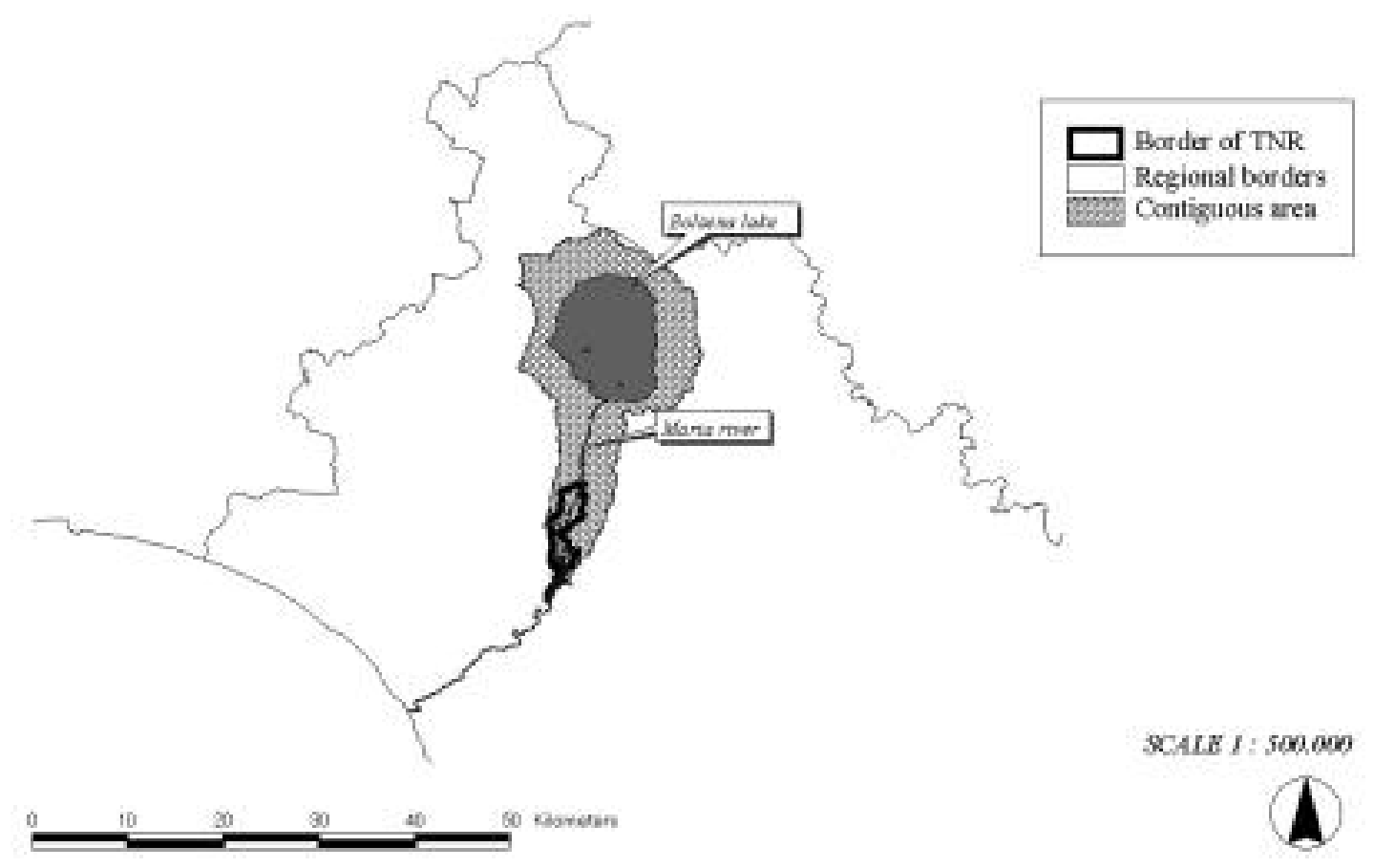

Fig. 3 - The proposed contiguous area for the Tuscania Natural Reserve.

\subsection{The Nature Reserve Regulations Document}

The Regulation Document (RD) is instituted by law 394/1991. It gives guidelines to discipline activities in the protected area, in order to readjust ecologi- cal and social imbalances, such as: agricultural practices, building constructions, roads construction, waste management, natural resources protection, possible fauna withdrawals and culling, etc. More details are in Table 2.

\begin{tabular}{|c|c|}
\hline $\begin{array}{l}\text { Immediate regulations } \\
\text { (imposed in the PAP) }\end{array}$ & $\begin{array}{c}\text { Postponed regulations } \\
\text { (to be worked out under PA management) }\end{array}$ \\
\hline Medieval centre buildings and farm tourism buildings. & $\begin{array}{l}\text { Activation of an Agenda } 21 \text { process for contiguous area } \\
\text { management. }\end{array}$ \\
\hline Potential structures and buildings serving the PA. & $\begin{array}{l}\text { Adoption of a suitable agricultural practice code, aiming } \\
\text { to preserve natural resources, increase the typical } \\
\text { products value of the area, give an economic boost. }\end{array}$ \\
\hline $\begin{array}{l}\text { Base rules governing agriculture, aimed at saving soil } \\
\text { from erosion and archaeological areas from deep tillage. }\end{array}$ & Code for the best management of riparian areas. \\
\hline Possible cycle and pedestrian routes. & $\begin{array}{l}\text { Rules on livestock, with special reference to waste } \\
\text { management. }\end{array}$ \\
\hline $\begin{array}{l}\text { Strategic solutions for the municipal and slaughter house } \\
\text { treatment plant. }\end{array}$ & $\begin{array}{l}\text { Definitive negotiations with the paper mill and the } \\
\text { electricity company managers to solve the Marta River } \\
\text { problems. }\end{array}$ \\
\hline $\begin{array}{l}\text { Strategic solutions for best sustainability of hydroelectric } \\
\text { plants on the Marta River. Preliminary negotiations with } \\
\text { the electricity company management. }\end{array}$ & $\begin{array}{l}\text { Detailed plan for sustainable tourist activities, developing } \\
\text { 'diffuse' hospitality in medieval town houses and farm- } \\
\text { houses. }\end{array}$ \\
\hline Guidelines for sustainable wood work activity. & $\begin{array}{l}\text { Opening the 'Park House', meeting PA people and } \\
\text { collecting Tuscania old traditions. }\end{array}$ \\
\hline $\begin{array}{l}\text { Preliminary negotiations with the paper mill } \\
\text { management. }\end{array}$ & $\begin{array}{l}\text { Organizing school and tourist visits to facilities in the } \\
\text { Park, such as the paper mill; the cork oak wood and its } \\
\text { harvesting; the most interesting natural sites (woods and } \\
\text { rivers); the Etruscan groves and the Etruscan water } \\
\text { collecting systems. }\end{array}$ \\
\hline
\end{tabular}

TABLE 2 - Tuscania Natural Reserve, more significant regulation document contents. 
The approach by which the RD was prepared in this plan consisted in giving it a strategic role, not a prescriptive one. In this way, it becomes a sort of platform of guidelines and rules for future management activities. Hence, two time phases are distinguished in the finished document: what should be done immediately and what should be left to a future phase, when the PA management is in full activity. The reasoning behind this division is to avoid setting rigid limits before the management can acquire the detailed knowledge that only the daily experience of running the PA can give. The PAP, in this way, will not lose strength, because the PA management authority will operate within its guidelines.

\subsection{Agreement within the community}

It is clear that it is not immediately easy for local people, above all a rural population, to accept a new protected area, because it means new limitations (real or simply feared) to the exploitation of the environment and a new authority (the Park Management Authority, MA), until now external to the traditional context. For those that do not respect rules (above all environmental laws), it signifies more controls. Such people are surely a minority, but they exist and are particularly combative. Moreover, there are more diffuse and relevant psychological reasons for resistance, regarding which, two different attitudes have been noted: (i) a general fear of change, deriving from the social structure; (ii) scepticism: people do not consider the protected area a concrete development opportunity and they have little trust in local administrators.

This is the context within which the planners carried out their work, which can surely be considered a frequent case [Forrester 1989]. In consequence, special effort is needed to communicate an image of the TNR as a development opportunity, above all from the tourism and agricultural points of view as a result of sustainable human exploitation. To achieve this, educating the local people's awareness is strategic. It will also help to overcome the initial opposition and diffidence of the local people towards the new entity. The fact that the planners and coordinators came from a University, considered an independent institution, and therefore above local factions and out of local hierarchies, was of significant help in carrying out this strategy. The strategy was completed by the effort of planners to gain the trust of the population and to demonstrate the usefulness of the nature reserve. Clear explanations and accountability of any planned action was the key of this strategy: all decisions were explained with transparency in public assemblies, in meeting with stakeholders and in single interviews with citizens. The main topic of discussion was the prohibition of hunting with the setting up of a PA. This interested above all farmers, who feared damage caused by wild animals. Another commonly expressed farmers' fear concerned limitations to agricultural activities. The Park Office also contributed to presenting a positive image to the public by spreading information, giving all the details on natural reserve institution advantages, on how to obtain reimbursements for wild fauna damage to crops, on land properties and PA limits (by cadastre map), on tourism development etc. Many citizens' proposals were accepted, which served both to enrich the PAP through sharing the precious experience of local people, and to persuade the latter to trust the planners.

Discussions at the park listening point and at public meetings, together with the constitution of a fund as an insurance against eventual wild fauna damage, helped to explain that this fear was unfounded and was being fed by rumours artfully spread by groups adverse to the PA. In fact, all the citizen and environmentalist associations participated actively; but also many single people and farmers spontaneously came to the Park Office asking for (and giving) news.

The most frequently asked questions at the listening point regarded border property: owners asked to check whether their properties lie inside the PA and what that entails. This was both very useful in designing the final border definition, and above all, it was important from the point of view of consensus collecting, because it became a way to familiarise oneself with farmhouse owners and to reassure them. All PA border owners were listened to and over $90 \%$ of them signed their willingness to be included in the protected area.

Important confirmation of the good results of the listening point includes that many owners asked to collaborate with the planners, in organizing footpaths and cycle paths in the PA.

\section{Discussion}

The general features of the PAP which are the result of the planning experience can be summarized as follows:

1) Ties and restrictions are an important component in PA planning and management, but they should be the last resort. Moreover, they should, in any case, be decided after in depth knowledge of the territory has been gathered and the public has been involved. They are undoubtedly easier for both planning and management phases and, hence, there is a strong temptation for planners and land managers to adopt them. However, both planners and land managers need to be aware of the risk in doing so: it could lead to PAs being characterized only by bureaucratic, "static" environmental protectionism. This in turn would become the main cause of opposition from the local population and scarce efficacy of the PA institution. Ties should be the last option, to be chosen only once managers have pursued all other possible solutions, and opened the PA to all the environmental and community problems. The "dynamic" task of the PAP reconciles these aspects with innovative models of development, based on environmental values, which do not 
merely impose limits.

The quality of a PAP can be evaluated, above all, according to how well the planners, and later the PA managers, interact with the PA citizens and stakeholders, because setting up a PA can easily create tensions, paralysing claims, threats and electoral blackmail (Forrester, 1989), that cannot be ignored.

2) The PAP should be "soft", assuming the characteristics of a master plan, which gives general guidelines and strategies for the management phase. For this reason, a strong PA management authority (MA) is required, with good scientific skills, supported by the shared strategies of the PAP, leaving the mode and time of their realisation to the MA.

3) Another relevant question consists in the integration between the PA and other plans, both environmental (landscape and water quality tutelage and soil conservation in this case) and general town planning. The PAP strategy in this sense consists in placing the TNR in the role of engine, a sort of catalyst entity in protecting the environment, in particular that of the Marta River and Lake Bolsena freshwaters.

These features are not explicitly present in the $394 / 1991$ law and are not frequent in Italian plans, in part because the law does not distinguish between different categories of nature reserves and in part because the same law is already dated: after 20 years, it requires revision, above all regarding the dynamic role of protected areas.

Table 3, from which the necessary innovations can clearly be seen, compares the planning processes employed in the common approach with those proposed in this paper. In the following paragraphs, the contents of the PA which lend it the above discussed characteristics are illustrated.

\subsection{Involvement of the population in planning}

Dialogue is important during the planning phase, but also during PA management once it has been set up and is running, following the path outlined by the PAP. It allows the PA to become a place of environmental awareness, knowledge and formation for the community and for economic interest groups. This also prevents conflicts between park and population, a problem that is spreading as PAs increase, above all regarding the IUCN Category $\mathrm{V}$ protected areas, which normally host numerous economic activities.

In consequence, the collaborative approach should continue throughout the management phase. To this aim, the TNR and the offices of the management authority should be located in the centre of a town which is part of the TNR territory and represents its history. It should become the "home of the park", responsible for maintaining the interest of local citizens with various initiatives, newsletters and debates, explanations of the decisions and also technical support for the implementation of the regulations.

\subsection{Involvement of the stakeholders in planning}

The main stakeholders are those responsible for the main economic activities within the protected area, the TNR PAP aims are( le due metà di questa frase non legano bene a mio avviso):

- Hydroelectric energy production. The TNR policy is to pursue the conversion of these plants into other plants producing renewable energy. Viable possibilities consist in substituting the present hydroenergy with solar and wind energy, a preliminary bill to this end was signed during the planning phase. This would allow the restoration of the Marta river, and such a project could become an eco-

\begin{tabular}{|l|l|l|}
\hline Planning processes & Common approach & Proposed approach \\
\hline Zoning & A milestone of the plan & $\begin{array}{l}\text { Zones not strictly bound, in particular } \\
\text { conservation A zones are not } \\
\text { necessarily strictly bound }\end{array}$ \\
\hline Buffer zone & A mere enlarged border & $\begin{array}{l}\text { A dynamic role, linking the park to } \\
\text { "common" land and to related land } \\
\text { planning, in this specific case, to river } \\
\text { basin planning }\end{array}$ \\
\hline Regulations Document & Prescriptive and detailed & $\begin{array}{l}\text { It gives guidelines and milestones, } \\
\text { leaving details to be decided by the } \\
\text { park management authority on the } \\
\text { basis of their increased knowledge } \\
\text { gained though the daily running of the } \\
\text { park }\end{array}$ \\
\hline Stakeholders' and local people's role & $\begin{array}{l}\text { Generic, and, as a consequence, } \\
\text { limited to listening and registering } \\
\text { complaints }\end{array}$ & $\begin{array}{l}\text { "Dynamic", because the purpose of } \\
\text { the process of listening to local } \\
\text { people is to aid relevant planning } \\
\text { decisions }\end{array}$ \\
\hline
\end{tabular}

TABLE 3 - A comparison between common PAP contents and innovative proposals. 
nomic flywheel for the whole territory, emphasizing the value of its relevant historical heritage. In consequence, the PAP pursues this strategy in order to safeguard the energy plant owners' economic interests and at the same time to meet the environmental need to free the Marta River from dams. The plan option consists in gradually promoting this aim, because any immediate plant transfers or closures, were judged unrealistic in the short term. This decision does not intend to remove the problem, but postpone it to the management phase, because it needs careful reflection and the highest possible degree of general consensus. It was therefore judged better to defer this work to the TNR Management Authority, giving only guidelines about this item in the PAP phase (in particular its Regulation Document).

- Paper mill plant. Two temporal phases are distinguished: over the long term, the objective is to relocate the factory, while the short term aim is to force the factory to adhere to the IPPC procedure and, during the PAP phase, technical support aimed at the latter goal has been given by planners.

This is the PAP strategy regarding the main economic activities: a "soft" approach, with very high attention to the context and to future PA management activities, without attempting any action which might result both immediately traumatic and difficult to implement.

Regarding the other main environmental threat (the wastewater treatment plant), this is the simplest case, because the only need consists in improving the existing plants. The presence of the nature reserve will facilitate the acquisition of the necessary funds, which is, moreover, a very good argument to help gain the trust of the local population and to demonstrate the usefulness of the protected area.

These details specific to the TNR, apart from what is of general interest, is the contribution that a protected area can act as a positive, sustainable land management catalyst, which can thus become an opportunity for obtaining local consensus and pursue a sustainable economic development.

On the other hand, the farmers, paper mill owners and hydro-electrical plant managers are the power structure of the local society and therefore the search for consensus, one of the milestones of the PAP, means that their views must be taken into consideration. This strategy cannot be based on simple ties and restrictions, it needs cooperation and consequent concerted decisions, in order to reach the goal of sustainable human activity.

In general, protected area plans, especially for Protected Landscapes, aim directly at species conservation, without studying sufficiently in depth either the context or the remote causes of threats to the environment. They tend to be specialized plans, confined in the nature conservation field, while they need the capacity of a holistic master plan, strongly linked to the regional planning context. This is particularly true in
Italy, probably because the framework law on protected areas is quite dated (1991, much older than environmental and landscape Italian laws: 2006 and 2004, respectively). For example, regarding the present study, the protection of EC "Habitat" Directive species for Marta river is officially an issue under the responsibility of the water protection plan, which however, does not have the means to deal with the level of detail required. Again, the PAP should work as a catalyser, a spur for the environmental plans regarding the Marta River.

This catalyzing action of the PAP towards higher quality, should be more general too, in this case: the improvement of the wastewater treatment of the Tuscania area sewage; the improvement of agricultural products, by increasing the sustainability of agricultural systems, in particular by reducing agrochemical export to the Marta River; favouring renewable energy production, but considering also that the Marta River has four dams for hydro-electrical power production. The consequences of the PAP's implementation will be the EC "Habitat" Directive species tutelage, an increase in tourist interest for the whole landscape and a generally more robust economic order for this territory.

In this way, biodiversity becomes an elementary part of the general discourse of global environmental management, giving a new meaning to 'nature' and nature reserves [Yliskylä 2003].

\subsection{Zoning}

The experience gained during this study has shown that the zoning method is not completely satisfactory, at least for V IUCN category PAs. In fact, to divide areas into homogeneous zones could be valid in urban areas, which can be divided by a simple line into zones with different vocations, above all from the point of view of building volumes and settlement, but even town planners are now debating its effectiveness and tend to move away from this approach, which, surely, cannot be reproduced for environmental systems. This is also true for landscape, where, by definition, it is impossible to define sharp barriers, particularly in Italy and in many European cultural landscapes, where nature and human activities have been strictly linked for thousands of years.

Zoning has been, and remains, one of the cornerstones of management for protected areas, but it should be given less emphasis by planners, who should recognize that it is not the answer to all PA planning/management problems. Modern environmental protection cannot be measured in terms of the number of protected hectares, nor those of quantity of core areas and related buffer zones, because the focus of sustainability is its specificity and in its consequent carrying capacity. Any scheme that demands uniformity in management (as proposed in [Caforio 1998]) should, therefore, be revised. What is really important is not zoning, but the possibility of constantly revising 
plans (and zoning), to follow the landscape dynamism and to drive land use towards sustainability.

This can be achieved by a robust PA geographic information system and a consequent PA Regulations Document, rather than by strict zoning.

\subsection{The buffer area}

Another meaningful aspect of the Tuscania Natural Reserve plan is the evaluation of its contiguous area. The "normal" approach in these cases follows the "ancient" logic of a core area of absolute protection, encircled, by zoning, into areas characterized by different degrees of protection and a further protection area, external to the PA, with a buffering role. In contrast, the TNR is formed around the river Marta, a typical open ecosystem, which defies the logic of core areas and related protection buffers. To respond adequately to the need of a buffer zone for this specific PA, the TNR plan identifies the Marta watershed, as defined by the PA [Fig. 2]. This is another demonstration of the need to differentiate between the strategic and applicative planning phases and related projects, to be undertaken by the MA. The TNR plan strategy consists in giving guidelines on land use sustainability and in promoting their application, by the MA, during the park land management phase.

In this way, the PAP becomes a protagonist of the area's development and an integrated part of the general land organisation and, even, a catalyser for the protection of of natural resources. This is its authentic role: not passive protection and enclosure, but as an engine and experimentation site for a new development of the whole landscape, both natural and cultural.

Furthermore, this approach allows the PAP to be linked to watershed planning, or, better, to provide guidelines for watershed planning.

The planners are aware that this choice is quite ambitious and will not be easy to apply, but it is a rational choice, deriving from the objective fact that any problems linked to water quantity and quality (the environmental focus for the TNR, but also for the habitat of European interest) originate from the river watershed and its land use. This "strong" statement of purpose is intended to encourage planners to pursue this difficult, yet fundamental, task.

It follows that one of the main management problems will consist in working out how to achieve this aim: a protected area plan, in fact, does not have the power to tackle these issues, since it lacks hierarchical authority over water resources or river basin authorities.

Hence, once again, the problem cannot be completely solved in the planning phase and the most useful action consists in suggesting, by means of the PAP, that the PA management should interact with the water authorities over the question of the Marta River and Lake Bolsena. There are two main PAP proposals: i) an Agenda 21 process, in which the PA managers would involve all the subjects having a vested interest in the specific environmental problem of the Marta River basin; ii) the drawing up of a special watershed plan to regulate, above all, water and land use. In Italy, basin planning was set up in 1989, thanks to Law N.183, which anticipated the European Water Framework Directive [2000/60/UE].

Agenda 21 is a programmatic document of environmental, economic and social issues, which contains the principles which should underlie sustainable development programs and policies, with the possibility of participation open to all the subjects and stakeholders, who have a stake in the territorial issues in question [UNCED 1992].

\subsection{The Regulations Document}

In common practice, the RD is very detailed and, in consequence, inevitably, its philosophy is essentially based on constraints and ties on land uses, because in the planning phase there is neither sufficient time nor sufficient awareness of very complex territory processes to distinguish the details that are typical of protected landscapes, generated by the complex interactions between nature and culture. Too many times, instead, they are not distinguished from strict nature reserves, managed mainly for wilderness and ecosystem protection, where it is normal that ties on land uses are the focus of management.

Hence, in this study, the final draught of each single regulation has been left to the TNR management authority, while the PAP sets out general strategies and guidelines for dealing with the TNR's problems. For example, thanks to archaeologists' work on the Etruscans remains, the plan lays the path for sustainable tourist exploitation of the area, but the detailed tourism plan has been left to the MA, which will be perfectly able to tackle this issue, thanks to accumulated experience.

Similarly, the RD lays the general path to assess agriculture sustainability, based on freshwater (Marta River) protection from agrochemicals; but it is left to the MA to construct a detailed geographic information system, thanks to which each farmer will have specific guidelines on how to pursue agriculture and livestock best management practices, also looking for economic viability for them. This approach clearly has the enormous potential for gaining farmers' trust and, in consequence, for transforming the PA from a "foreign" entity to a milestone of local development.

Another advantage of this approach consisted in giving managers/planners the possibility of coping with complexity, acquiring information and experience from the day to day running of the area, but also of debating decisions with stakeholders and private citizens.

These considerations provide the milestones of the TNR. Achieving, or failing to achieve them will mean the success, or failure, of the planned park. In the former case, the TNR will become an engine of sustain- 
able development, in the latter, the TNR will become a bureaucratic, useless agency. Indeed, even the local biodiversity and species habitat depend on these issues.

\section{Conclusions}

The study presented in this paper started from the experience of drawing up the plan for the Tuscania Natural Reserve (TNR), illustrating the specific vocation of the landscape, in its natural, historical and archaeological heritage.

The main characteristics of the TNR derive from the landscape's history, marked by the ancient presence of the Etruscans and by the successive slow evolution, whose roots lie in the High Middle Ages. The TNR's vocation as a rural and an archaeological park derives from these features, labelled as a V class in the IUCN classification of protected areas oriented towards sustainable exploitation. The focus for environmental sustainability is the Marta River/Lake Bolsena freshwater system and its water quality and quantity problems.

The results of this study suggest some applications of general interest and reproducibility, at least for this kind of protected area.

First of all, the method proposed can help to avoid the management jam, often characterized by a poorly integrated, disordered sum of ties and restrictions deriving from several plans (river basin, landscape, urban etc.), which is one of the fears of local people and stakeholders. PA planners, on the contrary, can gain people's trust by concretely tackling this problem and communicating their efforts and solutions clearly to local people. This, together with efforts to involve people in any planning process and aid in agricultural best management practices application, can help to transform a PAP into a reference point for the other plans that manage land use in the protected area.

Listening to people is not only a democratic coplanning tool, but also gives a relevant quantity of data, that can significantly improve the plan and the successive management, preventing opposition, fear of change and ideological contrasts.

To do this, a PAP should assume the character of a master plan, indicating strategies, general behaviour rules and land management milestones. Its implementation should be left to the day to day PA managers' work, whose in-depth knowledge, gained through management practice and the necessary dialogue with the population, stakeholders and other land managers, will allow them to write the detailed rules.

The main planning tools and phases should be adapted to these concepts, avoiding the current overrigid approach. In consequence, zoning should be optional and applied with prudence, while more relevance has to be given to the park Regulations Document.

In the same way, from the need to define the buffer area of the TNR, it emerged that it is not sufficient for it to be a simple transition area. Instead, it should be an active element, congruent with the ecological context (in the specific case focused on the Marta River basin) which can thus contribute to the PA's needs and aims.

Having this planning frame, the PA does not work as an external entity, but becomes organic to land management, cooperating with all the local territory's organisations (power structures, stakeholders, local policy makers, individual citizens, basin authority etc.) in creating a new landscape identity, based on environmental sustainability.

\section{References}

Antrop M., Why landscapes of the past are important for the future, Landscape and Urban Planning, 2005, 70, 2134.

Baudry J., Thenail C., Interaction between farming system, riparian zones, and landscape patterns: a case study in western France, 2004, Landscape and Urban Planning 67, 121-129.

Benkhard B., Relations Between IUCN-Zoning And Tourism In The Hungarian National Parks. Working Papers of the Finish Forest Research Institute, 2004, 377381.

Beresford M., Phillips A., Protected Landscapes: A Conservation Model for the $21^{\text {st }}$ Century, The Gorge Wright Forum 17, 2000, 15-26.

Boccia L., Ceccarelli L., Leone A., Ripa M.N., Salvatori V., Un'esperienza di pianificazione partecipata in area protetta. Estimo e Territorio, 2007, LXX, 19-26.

Buisson E., Dutroit T., 2006. Creation of the natural reserve of Crau: Implications for the creation and management of protected areas, Journal of Environmental Management, 2006, 80,318-326.

Caforio M., Lombardi P., Palella A., Pratesi I., Linee guida WWF per il piano del parco. Report WWF, 1998.

Clemens M.A., ReVelle C.S., Williams J.C., Reserve design for species preservation, European Journal of Operational Research, 1999, 112, 273-283.

Clement V., Spanish Wood Pasture: Origin and Durability of a Historical Wooded Landscape in Mediterranean Europe, Environment and History, 2008, 14 (1),67-87.

Council of Europe-UNEP, Protected areas and Ecological Networks. Eighth Meeting of the Council for the PanEuropean Biological and Landscape Diversity Strategy. Madrid, 2004, 19-21 January.

Forrester J., Planning in the face of power. Berkeley-University of California Press, 1989, 283.

Friedman S.K., Zube E.H., Assessing Landscape Dynamics in a Protected Area. Environmental Management, 1992, 16, 363-370.

Giacomini V., Romani F.V., Uomini e Parchi, ed. F. Angeli, Milano, 1982.

IUCN, Guidelines for Protected Area Management Categories, Gland, Switzerland, and Cambridge, UK., 1994, Report, 83.

Jongman R.H.G., Landscape Planning for Biological Diversity in Europe. Landscape Research, 2002, 27, 187-195. 
Kingsland S.E., Creating a science of nature reserve design: perspective from history. Environmental Modeling and Assessment, 2002, 7, 61-69.

Lacitignola D., Petrosillo I., Cataldi M. \& Zurlini G., Modelling socio-ecological tourism-based systems for sustainability. Ecological Modelling, 2007, 206, 191-204.

Liu X., Li J., Scientific solutions for the functional zoning of nature reserves in China, Ecological Modelling, 2008 , 215, (1-3), 237-246.

Marignani M., Rocchini D., Torri D., Chiarucci A., Maccherini S., Planning restoration in a cultural landscape in Italy using an object-based approach and historical analysis. Landscape and Urban Planning, 2008, 84, 28-37.

Mitchell N., Slaiby B., Benedict M., Developing Partnerships with Local Communities for Conservation of Protected Areas in North America: Recent Experience in The U.S.A. and Canada. Parks, 2002, 12, 2. IUCN, Gland, Switzerland, and Cambridge, UK.

Opdam P., Steingröver E., Van Rooij S., Ecological networks: A spatial concept for multi-actor planning of sustainable landscape. Landscape and Urban Planning, 2006, 75, 322-332

Palang H., Helmfrid S., Antrop M., Alumäe H., Rural Landscapes: past processes and future strategies. Landscape and Urban Planning, 2005, 70, 3-8.

Pelorosso R., Leone A., Boccia L., Land Cover and Land Use Change in the Italian Central Apennines: Comparison among Assessment Methods, Applied Geography, 2009, 29, 35-48.

Phillips A., Management Guidelines for IUCN Category V Protectes Areas. Protected Landscapes/Seascapes, Gland, Switzerland, and Cambridge, 2002, UK. XV, 122.

Scardozzi G., Tuscania, in: ed. Guaitoli M., Lo sguardo di Icaro. Le collezioni dell'Aerofototeca Nazionale per la conoscenza del territorio, 2003, Roma, 253-257.

Shafer C.L., National park and reserve planning to protect biological diversity: some basic elements. Landscape and Urban Planning, 1999, 44, 123-153.

Suckall N., Fraser E.D.G., Cooper T., Quinn C., 2009. Visitor perceptions of rural landscapes: A case study in the Peak District National Park, England, Journal of Environmental Management, 2009, (2), 1195-1203.

Trakolis D., 2001. Local people's perceptions of planning and management issues in Prespes Lakes National Park, Greece. Journal of Environmental Management, 2001, $61,227-241$.

UNCED, United Nations Organization Conference, Environment and Development, Agenda 21, 1992, Rio de Janeiro.
Willemen L., Hein L., van Mensvoort M.E.F, Verburg P.H., 2010. Space for people, plants, and livestock? Quantifying interactions among multiple landscape functions in a Dutch rural region. Ecological Indicators, 2010, 10, 6273.

Williams J.C., ReVelle C.S., Levin S.A., 2005. Spatial attributes and reserve design models: A review. Environmental Modeling and Assessment, 2005, 10, 163-181.

Young K.R., Wildlife conservation in the cultural landscapes of the central Andes, Landscape and Urban Planning, 1997, 38 (3-4), 137-147.

Yliskylä-Peuralahti J., Biodiversity - A new spatial challenge for Finnish agri-environmental policies? Journal of Rural Studies, 2003, 19, 215-231.

\section{SUMMARY}

Following the increase in protected territories over recent years, emphasis has been laid on improving nature conservation and management effectiveness. In particular, special attention has been given to areas where the interaction between people and the environment has produced a distinct character, rich in both ecological and cultural values. Such areas are known as Protected Landscapes and require a special planning and management focus, in which relevant weight is given to local people.

The aim of this research is to present a planning process case study in central Italy (Tuscania, north of Rome), where the protected area plan tackles nature conservation and environmental concerns (i.e. water quality, soil conservation, landscape restoration etc.). The results are of general interest because they are the fruit of an experience in debating and improving both the plan's contents and planning methods. In particular, they show: i) the primary role of local people in the various phases of planning, including delicate decisions such as the park's limits and its buffer area; ii) that a protected area plan should not be strictly prescriptive, but should have the role of a strategic master plan; iii) that the protected area policy should be emphasised in the park regulations document, rather than in rigid territorial zoning.

Keywords: Protected areas; land planning; landscape protection; participated planning. 


\section{The new functionalities of $w w w$. aiia.it}

The Italian Association of Agricultural Engineering has a presence on the World Wide Web since 2002, thanks to prof. Ettore Gasparetto. In the subsequent years the groups of Bologna and Milan have been responsible for maintaining the hardware and software structure, updating constantly the content according to the needing of AIIA presidents.

Recently this activity has received a new impulse from prof. Alessandro Santini, through a complete redesign of the setup, looking for a greater interface usability, easier updating of content and easier management of the ever growing database.

The first evidence of this transformation has been the moving from domain www.aiia.info toward the new www.aiia.it that has recently become available. It should be noted that the old domain aiia.info will remain online for few months, until the contract will expires. An automatic redirect is actually working for those who still connect to the old address.

The figure 1 shows the appearance of the new homepage, where the central space is dedicated to the most recent information. In the following text is reported a brief showcase of the most relevant features of the new AIIA portal.

(1) it is possible to translate in the main European languages the content of every page, using the small rectangular flag icons in the upper right corner. This is an automatic translation not very reliable, however capable to continuously adapt himself to the modifications in the pages content and will be probably sufficiently useful for international visitors.

Along the same line is available the banner "AIIA - Italian Society of Agricultural Engineering". This provide an active link that allows the user to return to the homepage from any internal page.

(2) On the left side there is a quick links column. The first link "Home" has the same goal of the banner "AIIA" in the top of the webpage.

The "Archivio News" (News Archive) opens an informative section, where the most important communications to AIIA members are stored. E.g. are reported news about periodic AIIA meetings or scientific conferences. Particularly the news are divided as information directly related to AIIA activity (AIIAnews) and others (AltreNews) such as CIOSTA conferences.

The "Journal of Agricultural Engineering" link points to specific web pages of the Journal of the Association: www.jae.unibo.it.

The fourth link "Storico Convegni AIIA" includes a list of the AIIA conferences held since 1966. Particularly, for the last one held in Ischia in September 2009, are stored even all the documents (in PDF format) divided by sessions.

All the stored documents are being indexed by the major search engines. As a consequence these papers, even in Italian, will gain a greater visibility.

Looking ahead, the webspace aiia.it could provide a base for the conservation of proceedings of next AIIA meetings.

The box below, "Calendario Convegni" (Meetings Schedule), is related to the AIIAnews section providing a useful visual representation of it. AIIA related events, past and planned, are shown on a monthly calendar.

It is sufficient to pass on the colored checkboxes with the mouse pointer to open a floating window that contains the specific information. One click leads on active link bring directly to the related page. As an example is possible to experience operating on April 2011.

The last box in the lower side provides specific areas for each of the seven sections of AIIA.

(3) this menu line it is probably self-explanatory. The first item "Storia" contains a chronology of AIIA activities since the foundation. The sections "Subscriptions" refer to the registration of new members (individual or collective), while "Struttura Organizzativa" describe the current composition of the board, the statute and rules of the Association. Moreover it is possible to search inside the directory of AIIA members. The item "Convegni" is obviously linked to the news section, being an archive of conferences of interest for AIIA. The interface of this section, very intuitive, allows some practical functions of sorting and searching. 
The item "Links Utili" (Useful Links) is designed to quickly connect aiia.it to other web structures of similar national and international associations: CIGR, EurAgEng and ISSA. Finally, the "Documenti" (Documents) section contains all the downloadable materials available on the site. This material is distributed across different pages and is referred from other part of the web structure, but could it be useful to find it quickly as aggregate.

(4) Among other features, that we invite to explore, we would highlight the internal search engine (see the small window "search" on the right side) and the "site map" link which shows (bottom right) a summary of the structure of the website dynamically generated, being so automatically updated.

All features are fairly intuitive to use, as a consequence we do not want insist here on deep details, considering sufficient just some direct experience. It with a group of tools whose operating modes are now part of the professional practice for all of us.

The developing and feeding of aiia.it is going on with the aim to offer new services, such as a periodical newsletter.

As a conclusion aiia.it is currently a versatile platform, ready to host and organize material that AIIA members will consider of general interest for association.

Angelo Fabbri

University of Bologna afabbri@agrsci.unibo.it

Fabrizio Sarghini

University of Napoli fabrizio.sarghini@unina.it 
